of adenosine into the cell ${ }^{4}$ the concentration of adenosine at the external adenosine receptors $\left(\mathrm{A}_{2}\right)$ is increased, leading to an augmentation of the vasodilatory effect of adenosine in intact coronary arteries. This situation, capable of producing coronary steal phenomenon, is similar to the enhancement of the extracellular adenosine concentration by intravenous injection of adenosine. Therefore it is not unreasonable to suggest that intravenous bolus injection of adenosine produces a transient coronary steal phenomenon, leading to chest pain in the six volunteers studied. As theophylline is also an antagonist at coronary $\mathrm{A}_{2}$ receptors ${ }^{5}$ the amelioration of chest pain by concomitant injection of this methylxanthine supports this view. The conclusion drawn by the authors that adenosine receptors have a role in mediating pain therefore appears somewhat premature.

Furthermore, intravenous injection of adenosine has been used to terminate paroxysmal supraventricular tachycardias in patients. ${ }^{67}$ In these studies only facial flushing was recorded as an adverse effect. As a reasonable number of patients (certainly more than 100) have been treated with similar doses of adenosine without chest pain a study on six patients is probably not sufficient to present a new clinically relevant aspect on the therapeutic use of adenosine.

M BÖHM

E ERDMANN

Klinikum Großhadern,

8000 München 70 ,

West Germany

1 Berne RM. The role of adenosine in the regulation of coronary blood flow. Circ Res 1980;47:807-13.

2 Belardinelli L, Fenton R, West A, Linden J, Althaus J, Berne $R M$. Extracellular action of adenosine and the antagonism by aminophylline on the atrioventricular conduction in the solated perfused guinea pig and rat hearts. Circ Res 1982;51 569-79.

3 Van Calker D, Muller N, Hamprecht B. Adenosine regulates by two different types of receptors the accumulation of cyclic AMP in culturd brin cells. N Nurochem 1979;33:999-1005. 4 K b bunde RE. Dipyridamole inhibition of adenosine metabolism in human blood. Eur $\mathcal{Y}$ Pharmacol 1983;93:21-6.

5 Bruns RF, Daly JW, Snyder SH. Adenosine receptor binding: structure activity analysis generates extremely potent xanthine antagonists. Proc Natl Acad Sci USA 1983;50:2077-80.

6 DiMarco JP, Sellers TD, Berne RM, West GA, Belardinelli L. Adenosine: electrophysiologic effects and therapeutic use for terminating paroxysmal supraventricular tachycardias. Circulation 1983;68:1254-63.

7 Belhassen B, Pelleg A. Acute management of paroxysma supraventricular tachycardia: verapamil, adenosine triphosphate or adenosine? Am $\mathcal{J}$ Cardiol 1984;54:225-7.

\section{Low concentrations of formaldehyde in bronchial asthma}

SIR,-Dr H Harving and colleagues (2 August, $p$ 310 ) exposed 15 asthmatic patients to low concentrations of formaldehyde fumes and found no significant changes physiologically or in the symptoms of asthma. They concluded that concentrations of formaldehyde found in the indoor environment were of minor importance in the development of pulmonary symptoms.

While I agree that asthmatics are usually no affected by formaldehyde, I think they should have been more positive about the importance of occupational asthma due to formaldehyde, which is a rare but distinct entity. They quote the work of Burge and colleagues ${ }^{1}$ but say only that such reports of occupational asthma "claimed" that it was due to hypersensitivity. In fact, occupational asthma due to formaldehyde has been recognised for almost 50 years $^{2}$ and is well documented.

Burge and colleagues actually described three "classic" examples and drew particular attention to the characteristic late asthmatic reactions that followed exposure at work and were also a feature of the subsequent positive bronchial provocation tests. The patients whom Dr Harving tested had not been working with formaldehyde and were therefore not eligible for hypersensitivity to the gas. Even asthmatics who work with formaldehyde are rarely affected by it, as shown by Nordman and colleagues, ${ }^{3}$ who found only 12 examples of "specific sensitisation to formaldehyde" among 230 asthmatics working with formaldehyde.

Cases of formaldehyde asthma have been reported not only from industry but also from hospitals, where formaldehyde is used for preserving pathological specimens and sterilising instruments. ${ }^{47}$ I hope that the Industrial Injuries Advisory Council, which recently increased from seven to 14 its list of "agents at work that cause asthma for which disablement benefit is payable" (23 August, p 513), will soon add formaldehyde to the list and give official recognition to those few unfortunate individuals who have been forced to give up their professions early or retire prematurely because of formaldehyde induced asthma.

Department of Lung Pathology,

BRIAN E HEARD

The Cardiothoracic Institute,

Brompton Hospital,

London SW3 6HP

1 Burge PS, Harries MG, Lam WK, et al. Occupational asthma due to formaldehyde. Thorax 1985;40:255-60.

2 Vaughan WT. The practice of allergy. St Louis: Mosby, 1939:677

Nordman H, Keskinen H, Tippurainen M. Formaldehyde asthma-rare or overlooked? I Allergy Clin Immunol 1985;75 91-9.

4 Hendrick DJ, Lane DJ. Formalin asthma in hospital staff BrMed f 1975;i:607-8.

5 Sakula A. Formalin asthma in hospital laboratory staff. Lancet 1975; ;i:816.

6 Gamble J. Effects of formaldehyde on the respiratory system. In: Gibson J, ed. Formaldehyde toxicing W ashington DC Hemisphere PC, 1983:175.

Newman Taylor AJ, Davies RJ, Hendrick DJ, Pepys J. Recurrent nocturnal asthmatic reactions to bronchial provocation tests. Clin Allergy 1979;9:213-9.

\section{Risk factors for uterine fibroids}

SIR,-The study by $\mathbf{R} \mathrm{K}$ Ross and others (9 August, $p$ 359) indicated that the risk of uterine fibromyomas decreased with increasing number of term pregnancies, longer oral contraceptive use, and cigarette smoking and was positively related with body weight. Since these risk factors are similar to those for endometrial cancer the authors speculated that women with endometrial cancer might have an increased prevalence of fibromyomas.

We analysed the relation between history of uterine fibromyomas and the risk of endometria cancer using information from a case-control study conducted in Milan in 1979-80. The data shown in the table, derived from a 1982 study, ${ }^{1}$ indicate that patients with endometrial cancer reported more frequently a history of uterine fibromyomas, with a relative risk of 3.0 ( $95 \%$ confidence interval 1.8 to $5 \cdot 1)$

This estimate is possibly inflated by detection or recall bias since patients with endometrial cance are particularly sensitised towards uterine complaints. None the less, the magnitude of the increased risk supports the hypothesis that uterine

Distribution of 173 patients with endometrial cancer and 347 controls according to history of uterine fibromyomas ${ }^{l}$

\begin{tabular}{lccc}
\hline $\begin{array}{l}\text { History of } \\
\text { fibromyomas }\end{array}$ & $\begin{array}{c}\text { Endometrial } \\
\text { cancer }\end{array}$ & Controls & $\begin{array}{c}\text { Relative risk } \\
(95 \% \mathrm{CI})^{\star}\end{array}$ \\
\hline No & 130 & 313 & $\begin{array}{c}1 \dagger \\
\text { Yes }\end{array}$ \\
Unknown & - & 32 & $3.0(1 \cdot 8$ to $5 \cdot 1)$ \\
\hline
\end{tabular}

$\mathrm{CI}=$ Confidence interval

*Adjusted for body weight and oestrogen use. †Reference category. fibromyomas and cancer of the corpus uteri have common aetiological mechanisms, possibly mediated through increased oestrogen availability.

Carlo la Vecchia

Instituto "Mario Negri,"

Milan,

Italy

Fabio ParazZinI AdRIANo DeCARLI

Instituto Biometria

University of Milan,

Italy

Silvia FranCESCHI

Contro Riferimento Oncologico,

Aviano (Pordenone),

Italy

1 La Vecchia C, Franceschi S, Gallus G, et al. Oestrogens and obesity as risk factors for endometrial cancer in Italy. Int $\mathrm{f}$ Epidemiol 1982;11:120-6.

Role of general practitioners in treating opiate misuse

SIR,--Mr Alan Glanz (30 August, p 543) suggests that general practitioners are loth to get involved in the care of drug misusers. While I cannot argue with the results of his questionnaire, I would seek to put a slightly different emphasis on the result. I would suggest that general practitioners' reluctance to deal with drug misusers often stems from the fact that we are responsible for the patients' total health rather than able to specialise in their particular problem of drug misuse.

Perhaps I may illustrate this by a patient of mine who, at the age of 43 , suffered a severe myocardial infarction; while he was recovering from this his wife died, leaving him with three small children. $\mathrm{He}$ developed angina and because of the family situation was rushed into hospital as soon as he developed chest pain. In order to try and prevent these frequent admissions he was given regular injections of opiates when he had the angina, and this led to his becoming habituated to this drug. The problem in his management was that we were responsible for his cardiac condition as well as his misuse of opiates. We were also under pressure from the casualty department to cut down on the number of admissions to hospital, and from the ambulance service to reduce the number of calls via 999. While this may sound like a sob story to justify the way in which we managed him, I suggest that it illustrates the problems of being on call day and night with patients having the right to telephone us and ask for help 365 days a year. The hospital drug unit has the advantage of having to deal with only the drug problem, and any medical problem that may arise can be dealt with separately by the general practitioner.

One further problem faced in present day general practice is that the use of rotas and deputising services makes it difficult to have a coordinated approach to drug misusers.

Lordshill Health Centre,

T BILlingtoN

Southampton SOI

\section{Is inexperience a defence against negligence?}

SIR,-Reading Clare Dyer's article (23 August, p 497), I notice that in none of the judgments she quotes is reference made to the junior doctor's ability to recognise when he is out of his depth. She quotes Lord Justice Glidewell as arguing that the law required the trainee or learner to be judged by the same standard as his more experienced colleagues, and that inexperience could be argued as a 